Supplement of Hydrol. Earth Syst. Sci., 24, 4831-4851, 2020

https://doi.org/10.5194/hess-24-4831-2020-supplement

(c) Author(s) 2020. This work is distributed under

the Creative Commons Attribution 4.0 License.

(c) (1)

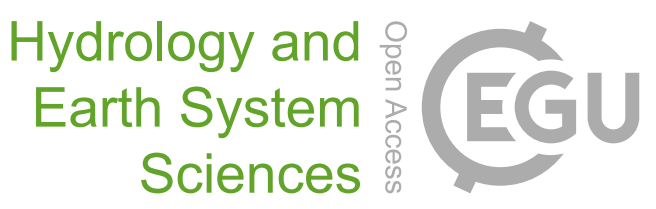

Supplement of

\title{
Assessing global water mass transfers from continents to oceans over the period 1948-2016
}

\section{Denise Cá}

Correspondence to: Denise Cáceres (d.caceres@em.uni-frankfurt.de)

The copyright of individual parts of the supplement might differ from the CC BY 4.0 License. 


\section{S1. Glacier data integration and evaluation of global glacier model}

\section{S1.1. Glacier data integration: pre-processing of gridded GGM output data}

For all three data sets (temporally accumulated glacier mass change, glacier area and precipitation on glacier area), the grid cells containing one or more glaciers ("glacierized" cells) were assigned to the corresponding cells of the WaterGAP grid

5 based on geographical location. As a consequence, 49 GGM glacierized cells were excluded from the analysis as they were outside the WaterGAP grid boundaries (Figure S1). Note that the accumulated global glacier mass change over 1948-2016 from the original data set (i.e. including all glacierized cells) amounts to $5730.63 \mathrm{Gt}$; after the exclusion of the 49 cells, it amounts to 5715.81 Gt. Hence, we consider that the effect of excluding these cells is negligible. Furthermore, the accumulated glacier mass change time series were disaggregated from monthly to daily because WaterGAP runs internally at

10 daily time steps. At the scale of one month, the temporal disaggregation was done by assigning the accumulated monthly value to the last day of the month and subsequently replacing the missing values (rest of the days in the month) by simple linear interpolation. Note that the first day of the simulation period was assigned the value 0 . The next step consisted in deriving the rate of daily glacier mass change from the accumulated daily values. Time series of precipitation on glacier area were also disaggregated from monthly to daily; at the scale of one month, this was done by simply dividing the monthly precipitation by the number of days in the month and assigning the resulting precipitation to each day of the month.

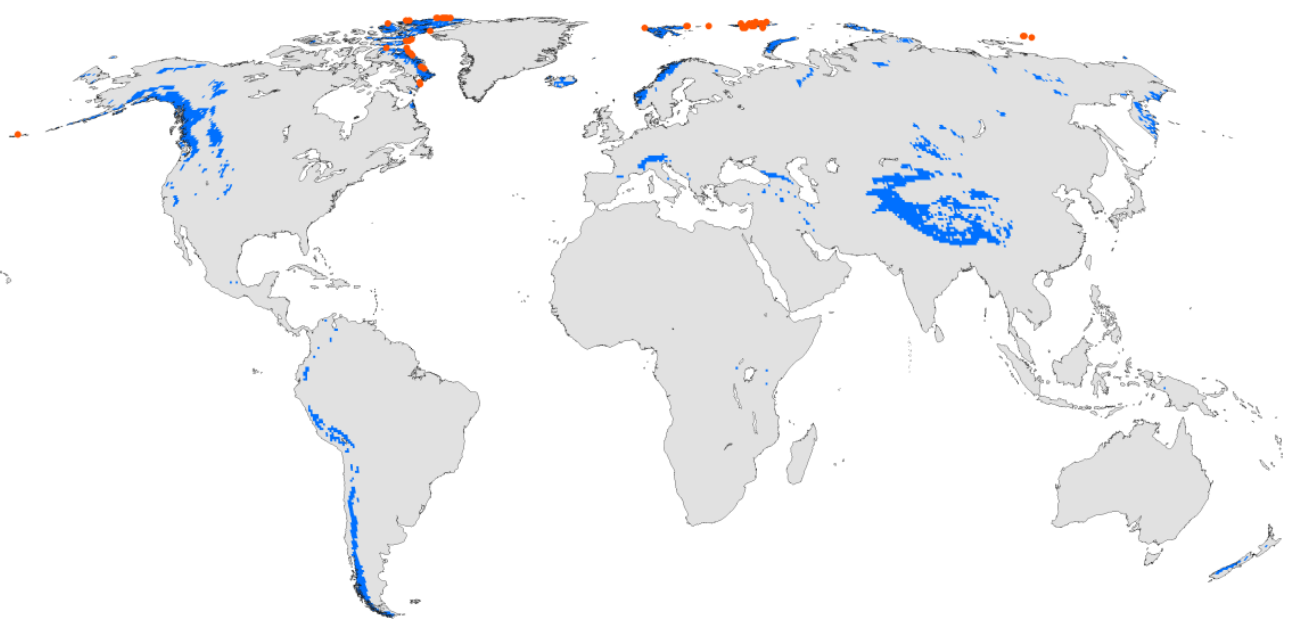

Figure S 1: Location of glacierized grid cells (from GGM gridded data) within (blue cells) and outside (orange dots) of the boundaries of the WATCH-CRU land-sea mask (used by WaterGAP). 


\section{S1.2. Evaluation of global glacier model}

25 Table S 1: List of individual glaciers considered for the comparison between observed and simulated glacier seasonal mass change. Observational data was obtained from the World Glacier Monitoring Service (2017). Modelled data was obtained with the global glacier model of Marzeion et al. (2012). NSE; Nash-Sutcliffe efficiency, r; correlation coefficient.

\begin{tabular}{|c|c|c|c|c|c|c|c|c|c|}
\hline $\begin{array}{l}\text { Glacier name } \\
\text { (RGI region) }\end{array}$ & $\begin{array}{l}\text { Number } \\
\text { of years } \\
\text { with obs. }\end{array}$ & $\begin{array}{l}\text { Area } \\
\left(\mathbf{k m}^{2},\right. \\
\text { 1950) }\end{array}$ & $\mathbf{r}$ & NSE & $\begin{array}{l}\text { Glacier name } \\
\text { (RGI region) }\end{array}$ & $\begin{array}{l}\text { Number } \\
\text { of years } \\
\text { with obs. }\end{array}$ & $\begin{array}{l}\text { Area } \\
\left(\mathbf{k m}^{2},\right. \\
\text { 1950) }\end{array}$ & $\mathbf{r}$ & NSE \\
\hline Gulkana (Alaska) & 49 & 17.57 & 0.97 & 0.23 & $\begin{array}{l}\text { Storglaciaeren } \\
\text { (Scandinavia) }\end{array}$ & 71 & 3.16 & 0.94 & 0.68 \\
\hline Wolverine (Alaska) & 49 & 0.03 & 0.97 & 0.86 & $\begin{array}{l}\text { Engabreen } \\
\text { (Scandinavia) }\end{array}$ & 46 & 42.95 & 0.98 & 0.93 \\
\hline $\begin{array}{l}\text { Melville South Ice Cap } \\
\text { (Western Canada and } \\
\text { US) }\end{array}$ & 39 & 1.24 & 0.9 & 0.77 & $\begin{array}{l}\text { Aalfotbreen } \\
\text { (Scandinavia) }\end{array}$ & 53 & 4.86 & 0.99 & 0.97 \\
\hline $\begin{array}{l}\text { Helm (Western Canada } \\
\text { and US) }\end{array}$ & 13 & 0.98 & 0.99 & 0.91 & $\begin{array}{l}\text { Vodopadniy (North } \\
\text { Asia) }\end{array}$ & 28 & 0.76 & 0.9 & 0.8 \\
\hline $\begin{array}{l}\text { Place (Western Canada } \\
\text { and US) }\end{array}$ & 24 & 3.02 & 0.99 & 0.98 & $\begin{array}{l}\text { Maliy Aktru (North } \\
\text { Asia) }\end{array}$ & 44 & 2.62 & 0.89 & 0.57 \\
\hline $\begin{array}{l}\text { Peyto (Western Canada } \\
\text { and US) }\end{array}$ & 27 & 9.7 & 0.97 & 0.72 & $\begin{array}{l}\text { Leviy Aktru (North } \\
\text { Asia) }\end{array}$ & 23 & 5.67 & 0.95 & 0.68 \\
\hline $\begin{array}{l}\text { South Cascade } \\
\text { (Western Canada and } \\
\text { US) }\end{array}$ & 51 & 3.55 & 0.99 & 0.97 & $\begin{array}{l}\text { Careser (Central } \\
\text { Europe) }\end{array}$ & 16 & 2.84 & 0.97 & 0.91 \\
\hline $\begin{array}{l}\text { Devon Ice Cap NW } \\
\text { (Arctic Canada North) }\end{array}$ & 54 & 765.44 & 0.94 & -0.68 & $\begin{array}{l}\text { Gries (Central } \\
\text { Europe) }\end{array}$ & 55 & 5.29 & 0.98 & 0.84 \\
\hline $\begin{array}{l}\text { Meighen Ice Cap } \\
\text { (Arctic Canada North) }\end{array}$ & 49 & 92.93 & 0.88 & 0.73 & $\begin{array}{l}\text { Sarennes (Central } \\
\text { Europe) }\end{array}$ & 68 & 0.44 & 0.96 & 0.85 \\
\hline $\begin{array}{l}\text { Midtre Lovenbreen } \\
\text { (Svalbard) }\end{array}$ & 38 & 5.21 & 0.96 & 0.9 & $\begin{array}{l}\text { Vernagtferner } \\
\text { (Central Europe) }\end{array}$ & 50 & 8.56 & 0.96 & -1.23 \\
\hline $\begin{array}{l}\text { Austre Broeggerbreen } \\
\text { (Svalbard) }\end{array}$ & 38 & 9.81 & 0.96 & 0.9 & $\begin{array}{l}\text { Silvretta (Central } \\
\text { Europe) }\end{array}$ & 57 & 2.88 & 0.97 & 0.92 \\
\hline $\begin{array}{l}\text { Rembesdalskaaka } \\
\text { (Scandinavia) }\end{array}$ & 53 & 16.83 & 0.97 & 0.88 & $\begin{array}{l}\text { Hintereis F. (Central } \\
\text { Europe) }\end{array}$ & 6 & 8.04 & 0.99 & 0.94 \\
\hline Storbreen (Scandinavia) & 67 & 5.21 & 0.98 & 0.97 & $\begin{array}{l}\text { Djankuat (Caucasus } \\
\text { and Middle East) }\end{array}$ & 47 & 1.76 & 0.99 & 0.85 \\
\hline $\begin{array}{l}\text { Graasubreen } \\
\text { (Scandinavia) }\end{array}$ & 54 & 2 & 0.96 & 0.48 & $\begin{array}{l}\text { TS. Tuyuksuyskiy } \\
\text { (Central Asia) }\end{array}$ & 50 & 2.84 & 0.93 & 0.52 \\
\hline $\begin{array}{l}\text { Hellstugubreen } \\
\text { (Scandinavia) }\end{array}$ & 54 & 3.28 & 0.98 & 0.94 & $\begin{array}{l}\text { Echaurren Norte } \\
\text { (Southern Andes) }\end{array}$ & 41 & 0.34 & 0.96 & 0.71 \\
\hline $\begin{array}{l}\text { Nigardsbreen } \\
\text { (Scandinavia) }\end{array}$ & 54 & 38.1 & 0.97 & 0.91 & & & & & \\
\hline
\end{tabular}



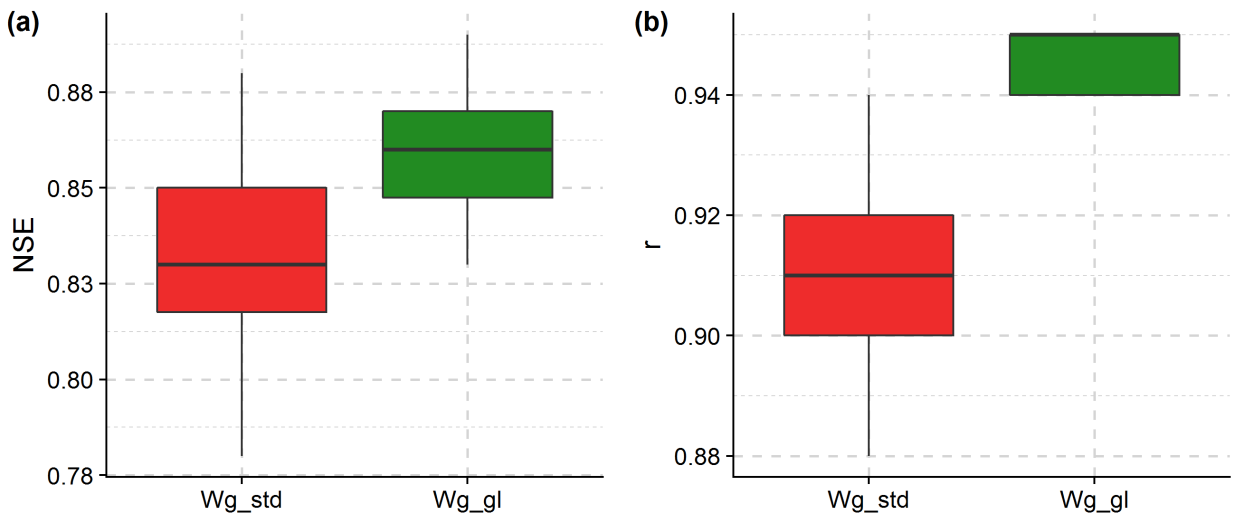

Figure S 2: Nash-Sutcliffe efficiency NSE (a) and correlation coefficient $r$ (b) obtained by comparing global monthly TWSA from GRACE observations and from two versions of WaterGAP2.2d, January 2003 to August 2016. Four GRACE-based TWSA time series were compared to four TWSA time series computed by standard WaterGAP (Wg_std) in anthropogenic mode (Wg_std_ant_CRU_irr100,

35 Wg_std_ant_CRU_irr70, Wg_std_ant_GPCC_irr100 and Wg_std_ant_GPCC_irr70 in Table 1) and to four TWSA time series computed by integrated WaterGAP $\left(\mathrm{Wg} \_\mathrm{gl}\right)$ in anthropogenic mode $(\mathrm{Wg}$ gl_ant_CRU_irr100, Wg_gl_ant_CRU_irr70, Wg_gl_ant_GPCC_irr100 and Wg_gl_ant_GPCC_irr70 in Table 1).

\section{S3. Global water transfer from continents to oceans over the period 1948-2016}

Table S 2: Linear trends of contribution of TWSA to ocean mass change over three periods (1948-1975, 1976-2002 and 2003-2016).

40 Estimates were obtained with four variants of integrated WaterGAP (same variants as in Figure 5a). Trends were calculated according to the least squares regression method. Positive trends translate to ocean mass gain, whereas negative trends translate to ocean mass loss. Millimetres of sea level equivalent (mm SLE) are relative to the global ocean area $\left(361.0 \cdot 10^{6} \mathrm{~km}^{2}\right)$.

\begin{tabular}{lccc}
\hline Model variant & & $\begin{array}{c}\text { Linear trend } \\
\text { mm SLE } \mathbf{~ r ~}^{-1}\end{array}$ & \\
& $\mathbf{1 9 4 8 - 1 9 7 5}$ & $\mathbf{1 9 7 6 - 2 0 0 2}$ & $\mathbf{2 0 0 3 - 2 0 1 6}$ \\
\hline Wg_gl_ant_GPCC_irr70 & 0.18 & 0.57 & 1.06 \\
Wg_gl_ant_GPCC_irr100 & 0.23 & 0.66 & 1.19 \\
Wg_gl_ant_CRU_irr70 & 0.13 & 0.49 & 1.18 \\
Wg_gl_ant_CRU_irr100 & 0.17 & 0.58 & 1.30 \\
\hline
\end{tabular}


Table S 3: Linear trends of contribution of individual water storage compartments to ocean mass change over three periods (1948-1975, 1976-2002 and 2003-2016). Positive trends translate to ocean mass gain, whereas negative trends translate to ocean mass loss. Ensemble

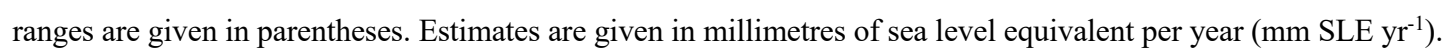

\begin{tabular}{lccc}
\hline \multicolumn{1}{c}{ Component } & \multicolumn{3}{c}{ Linear trend } \\
mm SLE y $\mathbf{- 1}^{-1}$ & \\
& $\mathbf{1 9 4 8}-\mathbf{1 9 7 5}$ & $\mathbf{1 9 7 6 - 2 0 0 2}$ & $\mathbf{2 0 0 3}-\mathbf{2 0 1 6}$ \\
\hline $\begin{array}{l}\text { Land glacier water storage } \\
\text { anomaly (LGWSA) }\end{array}$ & 0.38 & 0.37 & 0.77 \\
$\begin{array}{l}\text { Canopy water storage anomaly } \\
\text { (CnWSA) }\end{array}$ & 0.00 & 0.00 & 0.00 \\
$\begin{array}{l}\text { Snow water storage anomaly } \\
\text { (SnWSA) }\end{array}$ & -0.06 & 0.01 & 0.03 \\
$\begin{array}{l}\text { Soil moisture water storage } \\
\text { anomaly (SMWSA) }\end{array}$ & -0.01 & 0.01 & -0.01 \\
$\begin{array}{l}\text { Groundwater storage anomaly } \\
\text { (GWSA) }\end{array}$ & 0.11 & $(0.00$ to 0.02$)$ & $(-0.03$ to 0.00$)$ \\
$\begin{array}{l}\text { Lake water storage anomaly } \\
\text { (LaWSA) }\end{array}$ & -0.02 & 0.26 & 0.39 \\
$\begin{array}{l}\text { Wetland water storage } \\
\text { anomaly (WeWSA) }\end{array}$ & $(-0.02$ to -0.01$)$ & $(0.21$ to 0.32$)$ & $(0.32$ to 0.46$)$ \\
$\begin{array}{l}\text { Reservoir water storage } \\
\text { anomaly (ReWSA) }\end{array}$ & -0.01 & 0.00 & -0.01 \\
$\begin{array}{l}\text { River water storage anomaly } \\
\text { (RiWSA) }\end{array}$ & -0.01 to 0.00$)$ & $(0.00$ to 0.01$)$ & $(-0.01$ to 0.00$)$ \\
\hline
\end{tabular}

\section{S4. Caspian Sea net losses from GRACE solutions over the period January 2003 to August 2016}

For a first-order evaluation of Caspian Sea mass changes, we analysed the lake surface integration kernel (black squares in Figure S3) with a multi-parameter least-squares fit function including absolute, linear and semi-/annual terms. The assessed

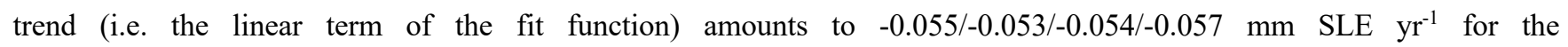
$55 \mathrm{ITSG} / \mathrm{CSR} / \mathrm{GFZ} / \mathrm{JPL}$ solutions, respectively (-0.055 mm SLE $\mathrm{yr}^{-1}$ on average). The fit uncertainties for the linear trend term

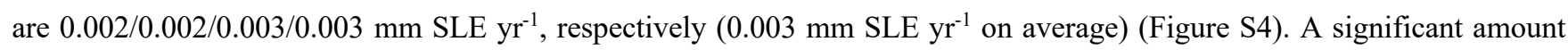
of leakage from the lake surface area is evident on-shore (Figure S3), but is not included in the integration kernel stated above. Without further analysis, we empirically estimate the out-leaking signal at $\sim 20 \%$ of the assessed kernel. 


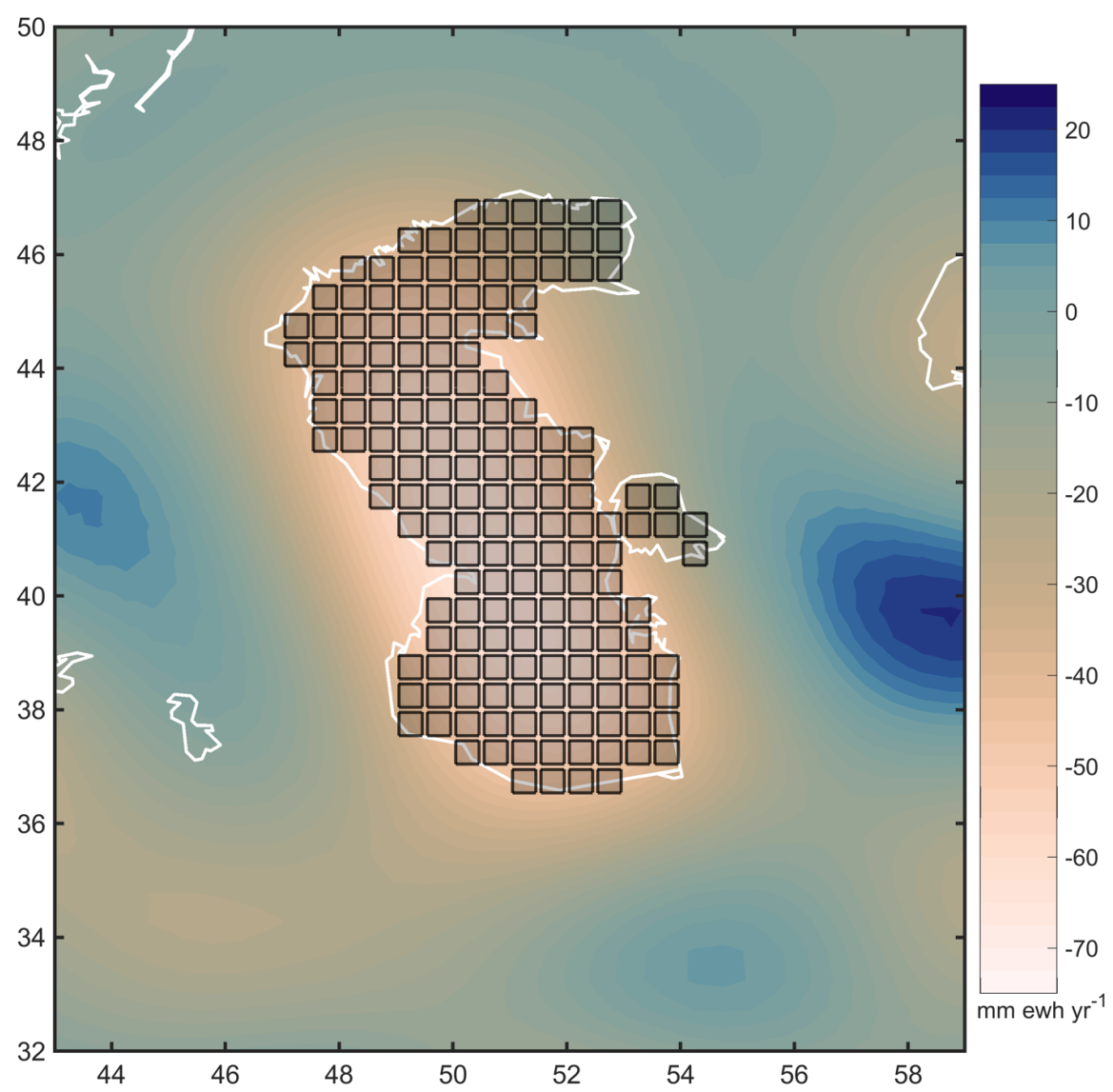

Figure S 3: Surface density change (linear trend 01-2003/08-2016) in the Caspian Sea area based on ITSG-Grace2018 monthly solutions up to degree and order 60; ewh: equivalent water height.

Please note that this test is not designed to replace an in-depth study of Caspian Sea mass change, but shall rather provide a

65 first-order evaluation of the possible trend difference between modelled TWSA and GRACE-based estimates introduced by different processing kernels in the Caspian Sea region. Nonetheless, including leakage, these GRACE estimates are well within the same range as results from dedicated work referenced in the main manuscript. 


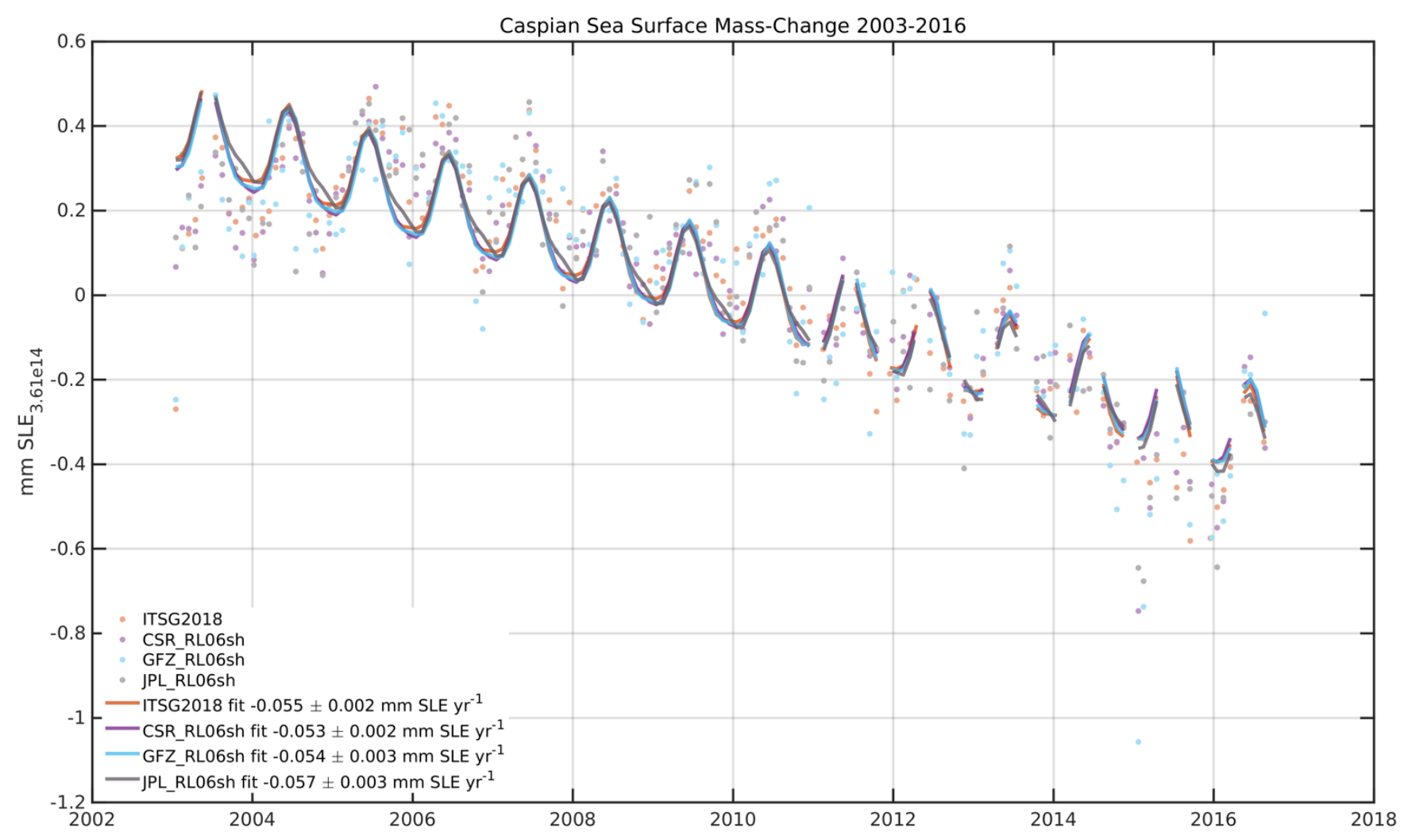

Figure S 4: Caspian Sea surface mass-change time series 01-2003/08-2016 estimated from ITSG-Grace2018 and CSR/GFZ/JPL GRACE

70 RL06 monthly solutions up to degree and order 60. Individual monthly mass values from GRACE are shown as dots; solid curves represent results of the multi-parameter least-squares fit. All values are plotted with reference to the 2006-2015 mean. Given the high long-term variability of the Caspian Sea volume, linear trend determination is obviously strongly dependent on the chosen time frame. Numbers given with the GRACE solution names in the figure indicate the assessed linear trend and its fit uncertainty, respectively.

\section{References}

75 Marzeion, B.; Jarosch, A. H.; Hofer, M. (2012): Past and future sea-level change from the surface mass balance of glaciers. In The Cryosphere 6 (6), pp. 1295-1322. DOI: 10.5194/tc-6-1295-2012.

World Glacier Monitoring Service (2017): Fluctuations of Glaciers Database. 